\title{
LOOKING UPSTREAM: INCREASING OPTIONS TO PreVent GenOcide
}

\author{
ISABELLE MACGREGOR AND \\ DEVIN C BOWLES
}

Genocide prevention scholarship focuses almost exclusively on immediate causes of genocide, those 'downstream' factors which tip an already troubled nation or region into committing atrocities. Neglected are those 'upstream' factors which trouble a nation or region in the first place. These include poverty, lack of freedom, education and health care, and environmental degradation and resource scarcity. While these are not direct causes of genocide, they contribute to them, thereby increasing the likelihood that genocide will occur. Because of the focus on interrupting the downstream causes of genocide-using measures which are implemented only when it is believed genocide is imminent-prevention analysis has generated strategies like sanctions, peacekeeping operations and prosecutions. Each of these measures has associated costs and is likely to be implemented by the international community in only a limited range of circumstances. Further, the triggers for the implementation of these measures generally involve serious discrimination and some level of violence, making it likely that even when fullblown genocide is averted, lives are nonetheless lost and tensions are raised within the society along ethnic or religious lines, increasing the long-term likelihood of genocide.

The upstream causes of genocide represent a number of prospective intervention points for prevention which have not received enough attention. These include the stimulation of the economy, the promotion of democracy, the provision of education and health care, and the protection and management of environmental resources. These measures are not new, but their role in genocide prevention has been largely unrecognised. While each upstream preventative 
measure is associated with implementation costs and factors making it unlikely to be implemented in certain situations, these costs and factors are different from those associated with downstream preventative measures, making the upstream measures a useful complement. By looking at both ends of the stream, genocide scholars can increase policy options for prevention, deterrence or deflection of the crime.

\section{Major causes of genocide in the literature}

To prevent genocide, we have to understand its root causes. Genocide and mass killing do not simply erupt spontaneously. They are incremental processes, building blocks, which aggregate and develop into their final form. The literature has produced diverse explanations. This essay focuses on structural causes. While precedent factors are analysed in the broader conflict-prevention literature, most scholars concentrates on the more 'last-minute' causes - those which have already been preceded by some level of violence. Few scholars trace the causes back to the contexts before the violence or repression began.

There are a number of possible genocidal catalysts. Helen Fein suggests war, challenges to the structure of domination, the threat of internal breakdown or social revolution, or economic development or recession $(1984,5)$. Many scholars see genocide as arising during periods of change, especially as Mark Levene argues (2000)-when empires, even nation states, are forming or crumbling. Genocide is sometimes seen as caused by hegemonic myths, and sometimes extreme religious views, which identify the victims as being outside the perpetrator's 'sanctioned universe of obligation' (Fein 1984, 18), for example, the Nazis' 'master race' myth. Genocide can also occur when a particular group becomes the scapegoat of an anxious state-when leaders believe that a particular group is weakening the already vulnerable state (Kuper 1984, 39). Genocide can be a retributive act against a group whose members have caused pain in the past. This becomes particularly likely where one group suddenly becomes the 
governing class and the other the subject class (Fein 1984, 11). Kuper points out that this can occur during the 'decolonisation of a two-tier structure of domination', as in Burundi and Rwanda following the withdrawal of the Belgian colonists (Kuper 1984, 34). 'Developmental' (Fein 1984) or 'creeping genocide' (Levene 1999) are the names given to a form which Kuper simply refers to as 'genocides against indigenous peoples' $(1984,32)$. These 'episodes' are aimed at getting rid of obstacles blocking the path of economic exploitation.

Straus argues for a general consensus in the recent genocide literature-for example, among scholars Mark Levene, Michael Mann, Manus Midlarsky, Jacques Semelin, Benjamin Valentino and Eric Weitz - that genocide develops from a process of 'escalation and contingency'. These analysts contend that there is a degree of improvisation and that genocide does not seem to be predetermined or inevitable. Straus adds that while this 'casts further doubt on the prospects of a general theory', if genocide is not highly preplanned, this should provide opportunities for the international community to 'shape outcomes' $(2007,492,493)$. These authors agree with Fein that war was (and is) an important factor in determining when and why genocide occurs (Straus 2007, 494)-demonstrating that genocide prevention scholarship can potentially benefit from the more general conflict-prevention literature.

\section{The conflict-prevention literature}

The existing genocide literature does very little to answer the question of why some conflicts escalate into genocidal killing and others do not (Valentino et al 2004). It is therefore difficult to know how to prevent a genocide. There is, nevertheless, a significant literature on conflict-prevention and, if genocide is one of the paths down which a disintegrating, conflict-ridden state can go-as Straus puts it, as 'part of a range of possible outcomes of violence' $(2007,500)$-this literature should be 
utilised.

The Carnegie Commission on Preventing Deadly Conflict outlines two broad strategies for conflict-prevention. Operational prevention involves measures in response to an immediate crisis. Structural prevention involves measures to keep crises from occurring in the first place, or to keep them from recurring (1997, xix). Structural prevention approaches 'not only make people better off but also inhibit the need to resort to violence' (Hamburg and Holl 1999, 368). It also involves the promotion of 'thriving states with representative government, the rule of law, robust civil societies and open economies with social safety nets' (Hamburg and Holl 1999, 368). It is this structural prevention, consisting of 'upstream' measures, which is lacking from the genocide literature. These include:

- Promoting indigenous democracy;

-Fostering equitable socio-economic development, for example, the provision of skills, knowledge, freedom and health; and

- Facilitating education on violence prevention, conflict resolution and mutual accommodation (Hamburg 2010b, 12).

Conflict-prevention requires a concerted, long-term strategy on the part of the international community, and this must encompass a wide range of developmental measures. No one element of a society can successfully be developed to the neglect of others - they must be developed in unison. As Hamburg and Holl state, 'economic growth without widespread sharing in the benefits of growth will not reduce prospects for violent conflict-and it could exacerbate tensions' $(1999,374)$.

The broader conflict-prevention literature presents a number of precursor events of violence that are, for the most part, not addressed. Linking with this broader field would thus provide genocide theorists with an increased number of potential upstream points of intervention. 


\section{Downstream genocide prevention strategies: an analysis and critique}

\section{Peacekeeping}

The most direct form of genocide prevention discussed is peacekeeping (Woodhouse, Bruce and Dando 1998, Shawcross 2001, Krasno, Hayes and Daniel 2003, and Lebor 2006). Its directness means that it does not rely heavily on theories of genocide causation. Military force is deployed to stop violent conflict with the threat or practice of violence which, borrowing from Clausewitz, forces potential genocidaires to do the peacekeeper's will (1950). ${ }^{1}$ The benefit of this option is that success in most circumstances is highly likely if the mission is adequately supported and if the primary goal of the mission is short-term genocide prevention. Unfortunately, these assumptions cannot be taken for granted because of the costs and limitations associated with such idealised intervention.

There are three main costs to outside countries deploying a peacekeeping mission: financial costs, the lives of its troops, and the commitment of its military forces. The capacity and willingness of would-be genocidaires to forcibly resist the intervention force dictates the size of these costs to the international community. Ideally, the intervention force has sufficient fighting capability to make the option of genocide unattractive to those who might otherwise engage in it, leading to a minimum of casualties both for the intervention force and locals. Constraining the international community's drive to deploy an overwhelming force are opportunity costs that come with military--the inability to project military force elsewhere-and financial costs. Even when an overwhelming

1 'War is thus an act of force to compel our enemy to do our will' (1950:3). 
international force is deployed, refinement of asymmetrical warfare puts it at risk, as demonstrated in Iraq and Afghanistan. Further, as genocide analyst Benjamin Valentino (2006, 740) argues:

'humanitarian intervention' is nothing more than another name for war. The ends of humanitarian intervention may be different from those of traditional wars, but the means are much the same. And as human rights advocates understand better than most, war is never cheap or clean. It seldom makes anything better without making something else worse.

Arms alone rarely change hearts and minds. One important limitation of peacekeeping missions is their failure to address the causes of genocide. Depending on the specific circumstances, a genocide prevention mission might have to support efforts to strengthen the rule of law, protect the integrity and independence of the judiciary, promote honesty and accountability in law enforcement, enhance protections for vulnerable groups, reintegrate ex-combatants and strengthen civilian control mechanisms. It might also be beneficial to provide support to local human rights organisations (ICISS report 2001, 23). Technical assistance for any equitable reform of the legislative, judicial or penal system could also be given (Cockell 2002, 197).

Yet the forced marriage between military intervention and civilian development is often problematic. If military missions are to reduce capability, and civilian missions are to enhance it, then international actors must be able to distinguish and effectively target the separate people and structures to be disempowered or strengthened. This task, particularly when genocide is imminent and there is a high level of internal tension within a society, is exceptionally difficult.

There is also the risk that foreign intervention - which is seen to benefit one group over another-will exacerbate internal conflicts. These unintended consequences of humanitarian intervention are liable to bog down military and civilian missions, leading either to premature withdrawal of 
international forces or increased costs to the countries supporting them.

The current geopolitical situation makes large-scale peacekeeping efforts to prevent genocide unlikely in the foreseeable future, for two reasons. First, the humanitarian intervention in Libya may have made international support for intervention less likely. To intervene in accordance with international law, an international force requires the authorisation either of the government of the country in which intervention is occurring or United Nations Security Council. Yet Russia and China viewed the recent military action in Libya as exceeding that which was authorised, making similar authorisations less likely to pass in the future, as has been shown by their veto of force in the current (20112012) Syrian uprising. This, in turn, may limit future humanitarian intervention to countries where governments acquiesce.

Second, demand for humanitarian intervention often exceeds what the international community is willing to offer. International police, such as UN police (UNPOL), represent the low end of the continuum of force which the international community might offer. International police deployments generally have lower human, financial and opportunity costs than full-scale humanitarian interventions. Despite international demand and the acknowledgement of its importance, UNPOLs deployable capacity is lacking. There is not adequate recruitment or preparation, and timely deployment of qualified police to new missions is therefore impaired. The UN is also currently unable to adequately manage and guide their police forces (Smith et al 2007, xiv). As Durch and Berkman state, 'serious lags in police deployments have been chronic' (2006, 44). After a UN mission, it takes approximately nine months for the authorised number of police personnel to deploy. Though member states must offer police personnel to the UN, they are 
generally reluctant to nominate officers, as police are often needed in their own countries and states do not like parting with them (Smith et al 2007, xiv).

Many of the countries which traditionally contribute to military intervention forces will be reluctant to do so in the future. Even before the global financial crisis, there were far more potentially pre-genocidal situations than there were forces to be deployed. It has traditionally been Western, technologically-advanced democracies which engage in peacekeeping missions. The global financial crisis has wrought havoc with the economies of the United States and the European Union as a whole. At the time of writing, the military budget of the United States is being reduced, impacting its war-fighting capability. Military deployments are exceptionally expensive, for instance the post 9/11 US wars in Afghanistan, Iraq and Pakistan are thought to have cost some \$4 trillion (Watson Institute for International Studies, Brown University, 2011). The financial situation of Western democracies dramatically reduces the likelihood that they will bear the costs of military engagement solely for the purpose of genocide prevention.

Additionally, many Western democracies are war-weary, having been engaged in Iraq and Afghanistan for years. Their people have little appetite to see more troops come home in coffins. Involvement in both these countries continues to stretch Western militaries, limiting their capacity to deploy forces elsewhere.

Libya provides an example. Colonel Muammar Gaddafi's government is believed to have participated in the bombing of civilian passenger Pan Am flight 103 from London to New York on 21 December 1988 (known as the 'Lockerbie bombing'). He also characterised those participating in a revolt against him as 'cockroaches', and threatened to execute all those who took up arms against him (Bellamy 2011), strongly suggesting that atrocity crimes were imminent. The opportunity to remove him from power and prevent 
impending atrocity crimes must surely rank highly on the list of scenarios in which Western democracies would be prepared to deploy military force in order to prevent genocide or other atrocity crimes. Yet they gambled that airstrikes and political pressure would be enough to achieve their aims, because of an unwillingness or inability to bear some or all of the three types of costs of further involvement. While Libya is now free of Gaddafi, it is unclear whether the fragmented opposition will cohere into a stable, democratic government. (The signs in mid-2012 were not hopeful, with increasing friction between tribal militias.)

In sum, humanitarian intervention is an important, lastminute tool to prevent genocide but a number of factors limit the circumstances under which it is likely to occur. The need for overwhelming force favours intervention by wealthy, technically-advanced countries and reduces the likelihood that any countries without a high level of military capability will intervene in this way. Yet these countries will have a low willingness to engage in such missions over the medium term. Intervention against potential genocidaires with advanced war fighting capabilities is also unlikely because of the need for military dominance. Finally, humanitarian intervention alone does little to address the causes of the genocide and can inflame underlying tensions within a society. At best, it simply decreases the intensity or extent of the violence; at worst, it increases suffering and exacerbates conflicts.

\section{Sanctions}

After a potential genocide has been detected, sanctions may prove an important preventative. Sanctions imposed on a state inhibit its ability to interact internationally, thus dissuading it from pursuing murderous policies (Doxey 1980, 9; ICISS report 2001, 29). This approach can be used in cases when general diplomatic pressure might not appear decisive enough but when the use of force is too extreme (Carter 1988, 12). 
For expository purposes, sanctions can be classified as economic, diplomatic or military, though overlap between categories occurs. Economic sanctions may target the foreign assets of a country or particular leaders. Restrictions on income-generating commodities such as oil, diamonds, timber and drugs are becoming common. Restricting access to petroleum can also restrict military operations (ICISS report 2001, 30)-although they can also prove disadvantageous in situations immediately preceding genocide as they could also immobilise the victim group. 'Freezing' assets is a common sanction (Alerassool 1993, 8, 20). Diplomatic sanctions often involve restrictions on diplomatic representation, including expulsion of diplomatic staff. This is largely symbolic and limits the possibility of illicit transactions like the sale of sanctioned goods, purchase of military-related material or the movement of funds. They might also prove disadvantageous if they diminish contact with the country and thus potential influence. Such sanctions include restrictions on travel for specific leaders. One form would be suspension or expulsion of the perpetrating state from international bodies (ICISS report 2001, 30). These sanctions are not likely to be successful on their own but they create severe inconveniences for the country's politicians and bureaucrats and cannot be ignored. Military sanctions can be effective. They can involve arms embargoes or the halting of military co-operation and training programs shared with that country (ICISS report 2001, 30).

The costs of sanctions to the international community are relatively small compared to armed intervention. Most sanctions involve the cutting of ties between participating sanctioning countries and the sanctioned country or group. The cost borne by each sanctioning country is therefore relatively small, as the sanctioned target accounts for only a small proportion of its economic, diplomatic, or military activity.

Sanctions have drawbacks. Most are blunt instruments that can be applied only to countries or a small number of individuals, rather than segments of the society. This can lead 
to civilians suffering because of sanctions directed at their government or prevent arms sales to victims of genocide, impeding self-defence. Once in place, sanctions can be difficult to lift. Each of these unintended consequences of sanctions can make genocide more likely. Additionally, to be most effective, any kind of embargo must be implemented quickly, often requiring the co-ordination of many countries.

Sanctions work best when targeted at either a few leaders or whole countries. There has been little success in applying most sanctions to large, potentially or actually genocidal social groups. For instance, during the 1990s, Bosnian Serbs could not be directly targeted by UN sanctions. Instead, the UN applied a range of sanctions against Yugoslavia, including freezing all Yugoslav financial assets on their territory, stemming the flow of hard currency into Serbia. The goal was to decrease Serbia's ability to support the Bosnian Serbs and prompt Belgrade to urge the Bosnian Serbs to make peace (Sloan 1998, 15, 46). While the Serbian leader Slobodan Milosevic publicly appealed to the Bosnian Serbs to accept the Vance-Owen peace plan (Sloan 1998, 48-49), neither his requests nor the sanctions were enough to halt Bosnian Serb violence.

Even when implemented quickly, sanctions are often indiscriminate weapons and can, on occasion, do more harm to the civilian population than to the targeted group (ICISS report 2001, 29). If the objective is to bring about economic and social disintegration, making it physically impossible for the state to continue its actions, sanctions may lead to the unexpected suffering and death of civilians (Kuyper 1978, 10). This was demonstrated when the UN imposed sanctions on Iraq in 1990. All transhipment of oil was forbidden as well as all trade with Iraq, except in medicine and food. They did not have the desired effect, instead causing harm to the Iraqi population. The magazine US News $\mathcal{E}$ World Report claimed in its 17 May 1993 issue: 'While ordinary Iraqis have suffered 
fearfully under the international sanctions, smugglers and clandestine sales of Iraqi oil have kept [Saddam] Hussein and his murderous coterie of hangers-on in relative comfort' (Summers 1995, 221). As Harff states, wherever possible, 'economic sanctions should not apply to domestic goods, those whose lack would endanger the survival of the population of the culprit state...' $(1984,153)$.

One claim is that civilian populations may be protected by 'smart sanctions', those designed to target specific decisionmaking personnel. This argument dovetails with Valentino's claim that leadership is an important cause of genocide and, where leaders see advantage in genocide, they will frequently pursue it as a strategy (Valentino 2004, 4-5). These might involve targeted 'financial sanctions, travel sanctions, specific commodity boycotts, and arms embargoes' (GAPWP Programme Statement 2008-2010, 24). According to Moller, 'smart sanctions' are not always smart. For example, there has been a travel ban on Robert Mugabe preventing him from flying out of Zimbabwe. This means that it will be harder for anyone in the country to overthrow him as there is always a greater possibility of ousting an absent leader. Smart sanctions, therefore, need to be tailor-made for each situation (2008). The risk is that the international community will outsmart itself with such sanctions; while efforts to use smart sanctions are frequently made, their negative effects are normally more diffuse than intended. Economic sanctions often hurt those already most disadvantaged, as more powerful groups ensure that their relative advantage is maintained. Even when not the case, the deprivation caused by sanctions can increase tensions within a society, making genocide more likely.

If genocides tend to occur when the balance of power is tipped drastically in favour of one group over another, then arms embargoes can in some situations make genocide more likely, as they prevent the less powerful side from arming itself. Bosnia demonstrated the problems which can arise in the implementation of military sanctions. The UNs blanket 
arms ban in the Balkans, imposed on 25 September 1991, left the two warring factions unevenly matched: the Muslims defenceless against well-equipped Serbs (Robertson 2002, 304; Krasno et al 2003, 239; Gow 1997, 37; Ramet 1999, 211). The Bosnian government repeatedly called for the embargo to be lifted to give the state and its threatened people a chance to defend themselves, claiming that it was an illegal breach of its right to self-defence under Article 51 of the UN Charter (Gow $1997,37,38)$. Once the UN arms embargo had been applied, it was extremely hard to reach an agreement to lift it-there would have to be a vote in the Security Council; France, the UK and Russia were unwilling to lift it (Gow 1997, 38).

Speed is essential for embargoes to work. If action is not immediate, the target state will have time to anticipate and adjust to sanctions, lessening their damaging impact (Kuyper $1978,10)$. It can do this through stockpiling materials, finding alternative sources, producing substitutes, stimulating and diversifying national production and imposing controls on key commodities (Kuyper 1978, 11; Doxey 1980, 106).

Because of the seeming decline of America's superpower status and the economic and military rise of developing countries like China, co-ordination between many countries is now required for effective sanctions. Yet group sanctions produce co-ordination problems. The countries involved may have different objectives. Many states, for economic or other reasons, do not apply sanctions strictly (Kuyper 1978, 10). Members of the UN, for example, generally avoid decisions about enforcement because they do not agree on culpability and are not prepared to undertake the inherent risks and costs (Doxey 1980, 81). Perhaps more importantly, governments often operate to maximise their own self-interest, rather than for any greater good. The Apartheid case in South Africa demonstrates a common situation where the self-interest of global superpowers ranked higher than their humanitarian ideals. Despite global opposition to the regime, serious 
international sanctions were blocked by the economic selfinterests of Britain and the United States. The first mandatory UN sanctions were imposed in December 1963. They were relatively weak, simply proscribing the shipment of equipment and materials for arms manufacture. No serious measures beyond this were adopted until 1985 (Institute for International Economics 1998). Britain and the United States refused to act because of their trade interests (Danaher 1989, $131,142,143)$. This illustrates the difficulties of international co-ordination.

\section{Punishment as a deterrent}

If the prosecution and punishment of genocidal criminals acts as a deterrent to others, then it might be viewed as an early prevention strategy. To be effective, prosecution must be rapid and consistent. Clearly this has not been the case. Trials have been inconsistent and slow even when they take place. The most effective forms of trial are most likely to be international tribunals, yet these are rare in the legal realm. After the Nuremberg and Tokyo trials of the Axis leaders, there were no new international tribunals until the Security Council created the international tribunals for Rwanda (ICTR) and the former Yugoslavia (ICTY) in the 1990s (Fierke 2005, 73). While the International Criminal Court (ICC) offers some hope, it prosecutes only when the suspect's own country refuses to do so and there is no guaranteed uniformity in procedure and sentencing (Lebor 2006, 221-20).

The deterrent effect of prosecution is lessened the longer it takes to bring criminals to justice, and is negated entirely if trials fail to take place. There was a significant lack of timely punishment for the genocide in Cambodia. It is only now that a UN-backed Cambodian tribunal has become a reality. The delays in Bosnia and lack of prosecution of leaders of the Sudanese genocide would give comfort to potential genocidaires calculating the odds of prosecution.

The costs of prosecution are often too great to bear, especially for a post-genocidal state. The traditional Gacaca 
system implemented in Rwanda is an example. There has been a conscientious effort to prosecute all those involved in the killing and throughout the 1990s, more than 100,000 suspects were forced to wait in detention. More than 18 years after the genocide, tens of thousands still awaited trial. This has been a huge economic burden on a country which is already one of the poorest in the world (Schabas 2005, 880; Fierens 2005, 900).

There are also drawbacks to using the possible deterrence capacity of prosecution as a preventative measure. The existence of tribunals can also serve to hamper the peace process: in a country where atrocities are continuing, the prospect of a trial means that it is more difficult to induce the combatants to sign a ceasefire (Bjorn Moller interview, Danish Institute for International Studies, 29 May 2008). The arrest warrant for Sudanese President Omar Hassan al-Bashir for genocide and crimes against humanity prompted concerns for the fate of a potential political settlement in Darfur and the hybrid United Nations-African Union peacekeeping force (Thakur 2008; de Waal and Stanton 2009).

Effective deterrent prosecution is unlikely to be implemented for several reasons. First, it requires significant finances and resources both on the part of the international community and the country in question. Second, it is often not possible if genocide suspects have fled or are being protected, potentially by a different country. Third, it might not be diplomatically expedient to press charges and risk a delicate peace settlement. Prosecution can only be classified as an upstream preventative measure if trials are speedy, efficient and uniform. As this is not the case, it probably has no significant deterrent impact and should be viewed as a downstream measure.

\section{Conclusions}

The three downstream prevention measures examined require 
a medium to high level of international co-operation to be implemented. Armed humanitarian intervention and sanctions require this co-operation to be achieved in a short space of time, once it is clear that genocide is likely. While there have been instances where this has occurred, an ideal policy toolbox would contain prevention measures that did not require a high level of international consensus.

Downstream measures also tend to rely on the knowledge that genocide is about to occur. This means that they are reliant on identification of pre-genocidal situations. While criteria for making such an assessment have been suggested (one of the most prominent examples is that of Fein, 1984), the prediction of genocide is hardly an exact science. Indicators may not provide sufficient detail regarding the kind, scale, time or place of these incidences. It is still not possible to predetermine the extent of the wider implications, for example, a subsequent refugee crisis (Thoolen 1992, 172-71). Beyond questions of timing and scale, there is room for doubt in any prediction of which situations might tip into genocide. Yet doubt provides countries which do not feel it is in their interests to intervene with an excuse for inaction. Even when all countries are operating with the best of intentions, the international community may not be able to bear the multiple costs of erring on the side of assuming that most or all potentially pre-genocidal situations will turn genocidal. This is particularly true for policy measures with high costs, such as armed humanitarian intervention and some forms of sanctions. Finally, if the international community hesitates until indicators of imminent genocide are recognisable, any measures implemented are likely to come too late to fully avoid death, suffering, and the hardening of ethnic and other divisions.

\section{Upstream genocide prevention strategies: a formulation and analysis}

The limitations of the downstream intervention measures discussed above call out for additional policy options, 
particularly those that are less costly and can be implemented unilaterally, well in advance of the genocide. Because of the problems of genocide prediction, they will need to be applied to a broad range of situations, some of which would not have become genocidal. Therefore, they should have positive outcomes beyond genocide prevention. Development aid meets all of these criteria, yet with very rare exceptions (Hamburg 2010a, Hamburg 2010b), the genocide literature pays little attention to development as a form of prevention. Development should ideally occur across a broad range of areas simultaneously, including those discussed below.

\section{Economy and infrastructure}

When poverty exists alongside ethnic or cultural divisions, mass killing can result. The provision of economic equality might thus prevent genocide. In the long term, there needs to be a general promotion of economic growth through better terms of trade. This involves allowing developing countries greater access to external markets, encouraging necessary economic and structural reform, and providing technical assistance for strengthening regulatory institutions (ICISS report 2001, 23). The World Bank launched its Operational Policy on Conflict and Development Cooperation in 2000, committing it to more vigorous action regarding countries at risk, experiencing or recovering from conflict (Cleves et al 2002, 322).

Economic development can increase risk of genocide if it occurs for just one group. Fein notes that development of unsettled land by states or multinational companies often creates conflict with the indigenous people, as profitable expansion provides the incentive to destroy indigenous people either directly or indirectly. She therefore advocates institutionalising human rights impact reports, similar to environmental impact reports, before such a project is approved $(1999,469)$. 


\section{Democracy and freedom}

Political inequality provides fertile ground for genocide. Promotion of democratic systems and values around the world is an important preventative measure. Democracies generally provide higher levels of 'public goods' to their populations than non-democracies. To maintain office, democratic leaders must win the support of a majority of citizens. In non-democracies, leaders owe their power to a smaller, less representative group of supporters (Valentino et al 2010, 529).

Countries in which rights and participation are based on ethnicity are more likely to lead to genocidal situations than nations which base rights on common citizenship. It is important to promote integration through establishing decentralised power-sharing and forums for multi-party dialogue. It might also be necessary for a peace-building mission to provide technical assistance to reform deficient governance institutions like the judiciary, the police or the civil service. Supervising transitional elections and supporting a free press is also significant (Cockell 2002, 197; ICISS report 2001, 23).

Conflict is common in societies which lack a democratic political system capable of managing disputes peacefully through dialogue, negotiation and compromise (SaveSoderbergh and Lennartsson 2002, 359). Preventative efforts should therefore ensure that all major groups in society participate in political power, administration, the army and police. It is not just a matter of creating democracy. Majority rule can still bring about the persecution of minorities, as was seen in Rwanda and Cambodia. A preventative mission should oversee the development of checks and balances in political institutions (Stewart 2002, 127). According to Horowitz, a mitigation of conflict can be achieved through the use of political incentives to encourage inter-ethnic moderation, for example, if politicians must rely in part on the votes of members of groups other than their own in order to 
be elected (Horowitz 2003, 12, 14). Establishing political inclusivity is particularly difficult; nevertheless, there have been instances in which it has almost certainly prevented conflict.

The UN planning and supervision of Cambodian elections in 1993 probably prevented future violence in that country. The aim was the introduction of democracy and peace to Cambodia, a country which had undergone 22 years of civil war. The United Nations Transitional Authority in Cambodia (UNTAC) protected the electoral process and ensured civil order, while the actual electoral process was run by UN volunteers. This involved the registration of the 4.8 million prospective voters. Despite difficulties, the electoral process was a success (Shawcross 2001, 54, 55, 63). The mission repatriated over 350,000 Cambodian refugees and opened up Cambodian society to 'press freedom, pluralism and grassroots organisations independent of the state and governing party' (Fawthrop and Jarvis 2005, 107).

Legal inequality is prevalent in high risk societies. The protection of law is an essential component of genocide prevention. The rule of law 'forms the basis for the just management of relations between and among people. It also helps ensure the protection of fundamental human rights, political access through participatory governance, social accommodation of diverse groups and equitable economic opportunity' (Hamburg and Holl 1999, 375). The promotion of justice should emphasise three areas: human rights, humanitarian law, and non-violent alternatives for resolving disputes, including more flexible intrastate mechanisms for mediation, arbitration, grievance recognition and social reconciliation. These areas require constant attention through democratic processes (Hamburg and Holl 1999, 375).

\section{Education and skills}

Education may be an important component of genocide 
prevention. As David Hamburg $(2008,1133)$ states:

Just as lifelong learning in mathematics, science, and technology is essential for the success of a modern economy, so too the teaching of pro-social behaviour across the lifespan can help to prevent immense destruction. This involves explicit information and hands-on experience with conflict resolution, violence prevention, mutual accommodation between groups, and conditions conducive to peaceful living.

It has been suggested that the education of women is a lucrative development investment in developing countries. Education increases the skills and choices of women, and of their children. Education also helps to delay marriage-partly because of an educated woman's greater chances for employment-and increase knowledge and use of family planning (Hamburg 2006, 37). Reduced population growth means that the society will place less pressure on environmental resources.

\section{Health care}

The links between health and peace have been underexplored. Furst et al state that 'an adverse public health situation may spur violent conflict, and violent conflict may favour the spread of infectious diseases'. Better understanding of this dynamic would help make critical infrastructure and public health systems 'crisis-proof' and thus reduce the occurrence of armed conflict (Furst et al 2009).

Health serves as an effective bridge to peace for several reasons. First, health is a shared interest valued throughout the world. Second, health interventions have an immediate impact of people's lives, as well as long term benefits. They inspire 'trust, confidence, and hope' in the societies in question and, in many cases, further development cannot be achieved without first reducing illness and death-for example, in African countries ravaged by AIDS. Third, health interventions are seen as largely non-ideological and thus more acceptable than some other programs (Hamburg 2006, 42). The advanced medical capabilities of Western nations 
place them in an excellent position to implement 'medical diplomacy' or 'health diplomacy'. Without clean drinking water and medical care, anger and frustration can grow within a society, leading to internal and regional conflict. Many of the world's current conflict zones-Sudan, Somalia, the Democratic Republic of Congo, the Palestine Authority and Sri Lanka-also 'bear disproportionate burdens of disease'. Medicine is rightly seen as a peacekeeping tool (Wexler 2009).

Beyond the direct links between health and peace, healthier populations are also more economically productive, providing a second route link peace (Hamburg 2006, 35). Health and internal stability are linked: 'healthy populations are able to work, cultivate food, and earn wages - all of which contribute to economic productivity and a functioning society' (Wexler 2009).

\section{Environmental protection and management}

The link between environmental protection and conflictprevention is recognised by scholars and policymakers outside genocide studies (Homer-Dixon and Blitt 1998). As Hamburg and Holl assert, natural resources often lie at the heart of conflicts which have the potential for 'mass violence'. Perpetrators sometimes manipulate resource shortages for their own ends, for example, using food or water scarcity as a weapon. Conflicts can also arise over competing claims of sovereignty over certain resources such as rivers or oil. Increasingly, there is 'environmental degradation and resource depletion in areas characterised by political instability, rapid population growth, chronic economic deprivation and societal stress' (Hamburg and Holl 1999, 373). Environmental management is important if we are to prevent genocide and mass killing. Hamburg and Holl argue that more effort is needed to develop 'sustainable strategies for social and economic progress' and that this sustainability is likely to become a key principle for development $(1999,373)$. 
In 2005, the Division of Early Warning and Assessment (DEWA), within the United Nations Environmental Programme (UNEP), developed the 'Environment and Conflict Prevention Initiative'. This initiative is designed to 'promote conflict-prevention, peace, and co-operation through environmental protection, restoration, and resources'. The environment becomes a 'pathway to co-operation' (Environmental Change and Security Program, Woodrow Wilson Center 2005). The Environment, Development and Sustainable Peace Initiative states that the protection of transboundary rivers in Africa is highly important. Water scarcity in Southern Africa increases potential for conflict in the 15 international river basins in that area. These rivers are also vital for socio-economic development, farming and hydroelectric power (Tanzler et al 2004, 13).

Conflicts based on environmental resources are most likely to occur in the world's poorest countries, those least able to implement sustainable development. The provision of assistance generally falls to multilateral agencies like the World Bank. This organisation is attempting to remedy the problem through distributing more than US\$ 20 billion annually and acting as a trustee for the Global Environment Facility (GEF). This facility is 'designed to add environmental dimensions to projects funded for more general development purposes' (Payne 1998).

Assistance packages might be used to tie border groups in one or more countries to their shared interests in land and water development and environmental protection (Hamburg and Holl 1999, 374). Environmental protection and development can also strengthen a country's economic growth and population health.

\section{Analysis and conclusions}

One drawback to development as genocide prevention is that it is unclear which, if any, genocides were prevented. This raises challenges for scholars seeking to study this form of prevention and for political leaders seeking to justify the 
costs. Valentino states that while the costs of prevention in a conflict will be much less than a purely reactive intervention, these costs must be multiplied many times because these prevention measures are likely to be applied to many crises that would never have become genocidal $(2006,735)$. But if prevention is based on developmental aid, then benefits include not just averted genocides, but the prevention of more conventional violent conflicts, decreased social unrest, reduced population growth, increased economic development, healthier populations and more robust environmental systems. These are valuable outcomes, not just for the country or region directly impacted, but for the world community.

Upstream intervention, and particularly development, also generally avoids issues of state sovereignty-a powerful restriction on downstream prevention. How does one justify forfeiture of state sovereignty to allow sanctions, a military presence or fact-finding investigations when no atrocity has yet been commit-ted? Even without the legal questions, until atrocities are committed, the people may 'prefer their tyrants rather than see their homeland overrun' (Teson 2003, 105-06). Few countries are likely to reject a broad, well-planned aid package on the grounds that it interferes with state sovereignty, even if they resist democratic reforms.

Options to prevent genocide must include more than only downstream policies. While these can be crucial to stop deadly violence, by themselves they do not result in real peace, only a cessation of violence. A wide-ranging program of aid and development is the best means of preventing genocide in the long term. Prosperous, healthy nations with educated populations and economic and legal equality are unlikely to witness genocide. Upstream strategies for prevention therefore seem to complement the downstream strategies on which genocide literature has focused and are worthy of exploration as methods to prevent genocide. 


\section{References}

Alerassool, M (1993), Freezing Assets: The USA and the most effective economic sanction, New York, St Martin's Press.

Bellamy A J (2011), 'Libya and the Responsibility to Protect: the exception and the norm', Ethics and International Affairs, vol 25; no 3, 263-69.

Carnegie Commission on Preventing Deadly Conflict (1997), Preventing Deadly Conflict, Final Report, New York, Carnegie Corporation.

Carter, B E (1988), International Economic Sanctions: Improving the haphazard US legal regime, Cambridge, Cambridge University Press.

Clausewitz, C von (1950, 1832), On War, Washington DC, Infantry Journal Press.

Cleves, P, Colletta, N, Sambanis, N (2002), 'Addressing Conflict: Emerging Policy at the World Bank', in Osler Hampson, F, Malone, D M (eds), From Reaction to Conflict Prevention, London, Lynne Rienner Publishers.

Cockell, J G (2002), 'Planning Preventive Action: Context, Strategy, and Implementation', in Osler Hampson, F, Malone, D M (eds) From Reaction to Conflict Prevention, London, Lynne Rienner Publishers.

Danaher, K (1989), 'The US Struggle Over Sanctions Against

South Africa', in Orkin, M (ed) Sanctions Against Apartheid, Cape Town, David Philip Publishers.

de Waal, A, Stanton, G H (2009), 'Should President Omar alBashir of Sudan be Charged and Arrested by the International Criminal Court?', Genocide Studies and Prevention, vol 4, no 3, 329-53.

Doxey, M P (1980), Economic Sanctions and International

Enforcement, New York, Oxford University Press.

Durch, W J, Berkman, T C (2006), Who Should Keep the Peace?

Providing security for twenty-first-century peace operations,

Washington DC, The Henry L. Stimson Centre.

Environmental Change and Security Program (2005),

Woodrow Wilson Center

http://www.wilsoncenter.org/index.cfm?fuseaction=topi cs.item\&news_id=114264\&topic_id=1413, accessed 18 
October 2009.

Fawthrop, T, Jarvis, H (eds) (2005), Getting Away With

Genocide? Elusive justice and the Khmer Rouge Tribunal, Sydney, UNSW Press.

Fein, H (1984), 'Scenarios of Genocide: Models of Genocide and Critical Responses', in Charny, I W (ed), Toward the Understanding and Prevention of Genocide: Proceedings of the international conference on the Holocaust and genocide, Boulder USA, Westview Press.

Fein, H (1992), 'Dangerous States and Endangered Peoples: Implications of Life Integrity Violations Analysis', in Rupesinghe, K, Kuroda, M (eds), Early Warning and Conflict Resolution, New York, St. Martin's Press.

Fein, H (1993) 'Accounting for genocide after 1945: Theories and some findings', International Journal on Minority and Group Rights, vol 1, no 2, 79-106.

Fierens, J, (2005), 'Gacaca Courts: Between Fantasy and Reality', Journal of International Criminal Justice, vol 3, no 4, 896-919.

Fierke, K M (2005), Diplomatic Interventions: Conflict and change in a globalizing world, Basingstoke UK, Palgrave Macmillan.

Furst, T, Raso, G, Acka, C A, Tschannen, A B, N'Goran, E K, Utzinger, J (2009), 'Dynamics of Socioeconomic Risk Factors for Neglected Tropical Diseases and Malaria in an Armed Conflict', in PLoS Neglected Tropical Disease. http://www.plosntds.org/article/info:doi\%2F10.1371\%2F journal.pntd.0000513 accessed 19 October 2009.

Global Action to Prevent War Project (GAPWP), Program Statement 2008-2010 (2007), Preventing Armed Violence and Ending War, http://www.globalactionpw.org/ accessed 15 June 2007.

Gow, J (1997), Triumph of the Lack of Will: International diplomacy and the Yugoslav war, London, Hurst \& Company. Hamburg, D A, Holl, J E (1999), 'Preventing Deadly Conflict: From global housekeeping to neighbourhood watch' in Global Public Goods: International co-operation in the 21st 
century, Kaul, I, Grunberg, I, Stern, M (eds), Oxford, Oxford University Press.

Hamburg, D A (2008), 'Education to Protect Humanity' (editorial), Science, vol 320, no 5880, 1133.

Hamburg, D A (2010a), Preventing Genocide: Practical steps toward early detection and effective action, Boulder $\mathrm{CO}$, Paradigm Publishers.

Hamburg, DA (2010b), 'Recent Advances in Preventing Mass Violence', Annals of the New York Academy of Sciences, Psychiatric and Neurologic Aspects of War, vol 1208, 10-14. Harff, B (1984), Genocide and Human Rights, Graduate School of International Studies, Denver, Northwestern University. Homer-Dixon, T and Blitt, J (eds) (1998), Ecoviolence: Links among environment, population, and security, Lanham, Rowman and Littlefield Publishers Inc.

Horowitz, D L (2003), 'The Cracked Foundations of the Right to Secede', Journal of Democracy, vol 14, no 2, 5-17.

International Commission on Intervention and State Sovereignty (ICISS) Report (2001), The Responsibility to Protect, Ottawa, The International Development Research Centre.

Institute for International Economics (1998) http://www.iie.com/research/topics/sanctions/southafri ca.cfm accessed 2 May 2006.

International Committee of the Red Cross (ICRC) (1999)

Arms availability and violations of international humanitarian law

http://www.icrc.org/web/eng/siteeng0.nsf/html/57JQ3 $\mathrm{M}$ accessed 19 October, 2009.

Krasno, J, Hayes, B C, Daniel, D C F (2003), Leverage for Success in United Nations Peace Operations, Westport, Praeger.

Kuper, L (1981), Genocide: Its political uses in the twentieth century, London, Penguin.

Kuyper, P J (1978), The Implementation of International Sanctions, The Netherlands, Sijthoff \& Noordhoff International Publishers.

Leaning, J (2002), 'Identifying Precursors', in Rittner, C, Roth, J 
K, Smith, J M (eds), Will Genocide Ever End?, St Paul MN, Paragon House.

Lebor, A (2006) 'Complicity with Evil': The United Nations in the age of modern genocide, New Haven, Yale University Press.

Levene, M (2000), 'Why is the Twentieth Century the Century of Genocide?', Journal of World History, vol 11, no 2, 305-36. Moller, Bjorn, (29 May 2008), personal communication with Isabelle Macgregor.

Payne, R (1998), 'The Limits and Promise of Environmental Conflict Prevention: The Case of the GEF', Journal of Peace Research, vol 35, no 3, 363-80.

Ramet, S R (1999), Balkan Babel: The disintegration of Yugoslavia from the death of Tito to the war for Kosovo, third edition, Oxford, Westview Press.

Robertson, G (2002), Crimes Against Humanity: The struggle for global justice, London, Penguin Books.

Save-Soderbergh, B, Lennartsson, I N (2002), 'Electoral

Assistance and Democratization', in Osler Hampson, F,

Malone, D M (eds), From Reaction to Conflict Prevention, London, Lynne Rienner Publishers.

Schabas, W A (1997), 'Sentencing by International Tribunals:

A human rights approach'

http://www.law.duke.edu/journals/djcil/articles/djcil7p 461.htm accessed 2 May 2006.

Schabas, W A,(2005), 'Genocide Trials and Gacaca Courts', Journal of International Criminal Justice, vol 3, no 4, 879-95.

Shawcross, W (2001), Deliver Us From Evil: Warlords and peacekeepers in a world of endless conflict, London, Bloomsbury Publishing.

Sloan, E C (1998), Bosnia and the New Collective Security, Westport, Praeger.

Smith, J G, Holt, V K, Durch, W J (2007), Enhancing United

Nations Capacity to Support Post-Conflict Policing and Rule of

Law, Stimson Center, Report No 63, Washington DC, The

Henry L Stimson Center.

Stewart, F (2002), 'Horizontal Inequalities as Source of 
Conflict', in Osler Hampson, F, Malone, D M (eds), From Reaction to Conflict Prevention, London, Lynne Rienner Publishers.

Straus, S (2007), 'Second-generation Comparative Research on Genocide', World Politics, vol 59, no 3, 476-501.

Summers, H G (1995), Persian Gulf War Almanac, New York, Facts on File.

Tanzler, D, Dabelko, G D, Carius, A (2004), Environmental Cooperation and Conflict Prevention at the World Summit on Sustainable Development, Adelphi Research, Mesoamerican Center for Sustainable Development of the Dry Tropics, National University of Costa Rica, The Environmental Change and Security Project (ECSP), Woodrow Wilson International Center for Scholars.

Teson, F R (2003), 'The liberal case for humanitarian intervention', in Holzgrefe, J L, Keohane, R O (eds) (2003), Humanitarian Intervention: Ethical, legal and political dilemmas, Cambridge, Cambridge University Press. Thakur, R (2008), 'Al-Bashir Arrest Controversy', Canberra Times, 15 July 2008 http://www.canberratimes.com.au/news/opinion/editor ial/general/albashir-arrest-controversy/810954.aspx accessed 20 August, 2008.

Thoolen, H (1992), 'Information Aspects of Humanitarian Early Warning', in Rupesinghe, K, Kuroda, M (eds), Early Warning and Conflict Resolution, New York, St Martin's Press.

Valentino, B, Huth, P, Balch-Lindsay, D (2004), 'Draining the Sea': Mass Killing and Guerrilla Warfare', International Organization, vol 58, no 2, 375-407.

Valentino, B (2006), 'The Perils of Limited Humanitarian Intervention: Lessons From the 1990s', Wisconsin International Law Journal, vol 24, no 3, 724-40.

Valentino, B, Huth, P K, Croco, S E (2010), 'Bear Any Burden? How Democracies Minimize the Costs of War', The Journal of Politics, vol 72, no 2, 528-44.

Watson Institute for International Studies, Brown University (2011), The Eisenhower 'Costs of War' Research Project, 
http://costsofwar.org/ accessed 30 July 2011.

Weitz, E D (2003), A Century of Genocide: Utopias of race and nation, Princeton and Oxford, Princeton University Press.

Wexler, R (2009), 'Medical Relief: Effective diplomacy', The Diplomatic Courier: A Global Affairs Magazine www.diplomaticourier.org accessed 11 October 2009.

Woodhouse, T, Bruce, R, Dando, M (eds) (1998), Peacekeeping and Peacemaking: Towards effective intervention in post-cold war conflicts, London, Macmillan Press. 